\title{
Information-seeking patterns of artists and art scholars at the Vaal Triangle Technikon
}

\author{
Carol van Zijl \\ Gold Fields Library, Vaal Triangle Technikon, Private Bag X021, Vanderbijlpark, 1900 Republic of South Africa \\ carolvz@vtt_nt.tritek.ac.za
}

Elizabeth M. Gericke

Department of Information Science, University of South Africa, P.O. Box 392, Pretoria, 0003 Republic of South Africa

gericem@alpha.unisa.ac.za

\begin{abstract}
A survey was carried out amongst the full-time lecturers in the Art Department at the Vaal Triangle Technikon to ascertain their information-seeking behaviour for scholarly pursuits. The instrument used was a selfadministered questionnaire wherein the lecturers were asked to grade certain sources and information-seeking patterns as to their usefulness. It was found that overall, the preferred information sources were (in order of preference) periodical articles, library books, personal contact with other scholars in the field, books in private collections, visits of art galleries and the Internet. When these findings were analysed according to field of expertise, qualifications, age and gender, different preferences were displayed for the various groups of artists. As far as information-seeking behaviour is concerned, the preferred methods in order of preference are conducting own searches in catalogues or OPACs, asking a librarian and searching on the Internet. Here again the different groups demonstrated different preferences. There appears to be a place for both print and electronic media in the information-seeking preferences of artists and an increasing interest in electronic media has serious implications for information providers of the future.
\end{abstract}

'n Opname is gedoen onder die voltydse dosente in die Kunsdepartement van die Vaaldriehoekse Technikon om hul inligtingherwinningsmetodes vir hul akademiese werksaamhede vas te stel. Die gekose instrument was 'n vraelys wat deur die respondente self voltooi is. Die dosente is gevra om sekere bronne en inligtingherwinningspatrone te gradeer volgens hulle bruikbaarheid. Daar is gevind dat die inligtingsbronne van voorkeur (gerangskik volgens belangrikheid) in die geheel, tydskrifartikels, biblioteekboeke, persoonlike kontak met ander kenners in hulle veld, boeke in eie versamelings, besoeke aan kunsgallerye en die Internet is. Ontleding van die bevindinge volgens vakgebied, kwalifikasies, ouderdom en geslag, het verskillende voorkeure vir die verskeie groepe kunstenaars na vore gebring. Sover dit inligtingherwinningsmetodes betref, is die belangrikste metodes (weereens in orde van belangrikheid) om eie soektogte uit te voer deur middel van katalogi of 'online public access catalogues' (OPACs), om 'n bibliotekaris te vra en om soektogte deur die Internet te doen. Hier het die verskillende groepe ook verskillende patrone geopenbaar. Beide gedrukte en elektroniese media is duidelik nog belangrik vir kunstenaars en die toenemende belangstelling in elektroniese media het belangrike implikasies vir toekomstige inligtingsverskaffers.

The purpose of this article is to investigate the distinctive information-seeking needs and behaviour of artists and art historians. Research into this area of user studies needs some attention, as is made clear by the few writers on this topic (Cobbledick 1996; Lane 1994). To place the survey conducted amongst the lecturers at the Vaal Triangle Technikon into perspective, an extensive summary of the literature regarding previous readership studies in this regard will be included. As information resources evolve towards electronically-transmitted data, it would be valuable to ascertain to what extent this has altered the information-seeking patterns of artists.

\section{Literature}

In general, the literature dealing with the informationseeking behaviour of artists can be divided into studies of the use of print media like monographs, periodicals, image representations and exhibition catalogues, and that which involves electronic or digital information sources, such as online databases, CD-ROMs, and the Internet. Findings will be divided into these categories in this article to show what has been concluded and the use of these media by artists and visual arts scholars. The information used and produced in the visual arts is of a less empirical nature than in the more scientific disciplines and therefore relies quite heavily on personal interpretations and critical judgments. This has a considerable effect on the information-seeking behaviour of artists.

Budd (1989:4-17) provides a valuable synopsis of the nature of information in the humanities, all of which also applies to the visual arts. $\mathrm{He}$ has found that the descriptions, informed opinions and critical evaluations 
contained in the information mean that the latter is more subjective than in other disciplines. This factor also has the implication that the humanities scholar relies heavily on his own ideas and insights during research (Stone 1982:71). The humanities are largely nonparadigmatic. This means that the information created is not verifiable or replicable, each source of information expresses the ideas and sentiments of the individual writer or researcher and cannot be automatically transferred to other research projects. This also means that the information is noncumulative. There is a low degree of obsolescence in the humanities literature. This means that sources which were valuable when created do not become less important over the passage of time. Scholars and researchers can thus draw on all of the material written at any time on a certain subject. This observation is borne out by Stone (1982:303) who writes that the time-scales used in the humanities are different from those in other disciplines.

Humanities and visual arts scholars display a tendency to browse through the sources to find interesting information and also seem to rely heavily on serendipity to find unexpected and valuable information (Budd 1989:9; Case 1986: 99; Stone 1982:301).

Budd (1989:9) and Stone (1982:296) found that researchers in the humanities place much store on the library in their information-seeking endeavours, and also seem to prefer to find their information themselves, without relying on an intermediary like a librarian. An important requirement for the humanities researcher is a well-stocked library with open access to the collection.

Layne (1994:28) identified a problem in the assignment of access points in the visual arts. Some artists are known by several names, for example Michelangelo is known as Michelangelo, Michelange, et cetra and even works of art have various titles, for example the Mona Lisa is also known as la Giaconde. It can be difficult to specify the nationality of an artist, which further confuses both the assignor or subject headings and the scholar seeking information. Gauguin, for example, is a French painter who spent a great deal of his life painting in Tahiti, and many artists move around, making it difficult to decide which country to identify him with. The identifying style of an artist is also difficult to specify, because many artists change their styles over time (Layne 1994:30). Finding works of art on a particular subject, as is often required by visual arts scholars and researchers, is also very exacting, because many works deal with a variety of subjects, making it very difficult to find works dealing with a particular subject, as is required for comparison purposes.

It would be remiss not to mention the importance of the invisible college of colleagues, fellow artists and art scholars in a discussion of the information-seeking needs and behaviour of visual artists. In the past, and possibly still today, this took the form of face-to-face encounters and discussions between like-minded scholars, but Brown (1990:372) and Cronin (1982:70) believe that increasing use is being made of electronic means of communication. Facilities such as electronic mail (e-mail), fax, electronic bulletin boards, computer conferencing, newsgroups, listservs, and other telecommunication channels are becoming increasingly important to all researchers, and also to those in the field of the visual arts.

Lönnqvist (1990:197) has found that visual arts scholars need more than just libraries to meet their needs. They also need access to collections in galleries and museums and special collections of art works. Art scholars often prefer to have their own core collections of reference sources.

\section{Use of print media}

There is a large volume of research findings and discussion which points to the fact that visual artists rely heavily on print media to meet their information needs.

\section{Books}

Stone (1982:296) found that the most used format in the humanities is the monograph because retrospective coverage is easier in this format. Simonton (Budd 1989:12) has found that this trend is duplicated in the fine arts. Reference works like encyclopaedias and Janson's History of art, Arnason's History of modern art and Gardner's art through the ages were found very valuable to art researchers (Rees 1987:28). Lönnqvist (1990:200) found that for new research, scholars 'tend to start with standard works and handbooks.

\section{Periodicals and indexing and abstracting tools}

Periodical articles are also widely used, but indexing and abstracting sources in the visual arts is not as satisfactory as in the sciences. They are also updated less often (Budd 1989: 10). Stone (1982:297) did, however, find that art researchers use bibliographies, indexes, abstracts and other bibliographic tools to look for relevant articles. Judging by the date of his article, he was referring mainly to printed indexing and abstracting tools.

\section{Visual material}

An information need peculiar to scholars in the visual arts is for visual material, in particular for works of art or representations of these works. Layne (1994:25) found that art scholars need images as examples of techniques, as representations of specific objects and as examples of certain moods. They often need to be able to browse through images. Art historians also need to study images as art objects. This means that these scholars need to visit the actual galleries or art museums in which the works are housed to locate the work if possible or else find the picture in another information source. There are many valuable information sources which help the scholar in this regard, including several indexes to images like World painting index, Art in time and Illustration index but these are not always very helpful or complete (Layne 1994:33).

Exhibition catalogues and the published ephemera accompanying exhibitions are also very useful primary sources 
when looking for works by little-known and recent artists (Layne 1994:33). These are very important to scholars as they often contain the artists' own interpretation of their works (Robertson 1989:32). Access to these exhibition catalogues is, however, not easy.

\section{Use of electronic media}

The rapid growth of information technology could have a great influence on the information-seeking behaviour of visual arts researchers and scholars, but this aspect has not been documented very extensively.

\section{Online databases}

There are not as many bibliographic databases relating to the visual arts as there are for more 'financially robust' disciplines (Greenhalgh 1996:97; Muratori 1989:40). Online databases include Wilsonline, Art abstracts, Art index, RILA, Avery index to architectural periodicals, and a few others which concentrate specifically on the visual arts. There are several problems in the use of online art-related databases according to Walter (1991:3). There is limited subject coverage, poor retrospective indexing of material (anything published before the 1970s is unlikely to be included in these databases), lack of regular updating and of co-ordination between services and there are difficulties relating to the vocabulary used in this field. There is also a lack of conformity in the access points used.

\section{$C D-R O M S$}

The CD-ROM industry changed the information provision possibilities for the visual arts considerably. First this technology was used to provide indexing and abstracting services on a subscription basis to information users. Art index is a good example of this use of CD-ROMs. In a survey carried out by Sykes-Austin (1991:13), users showed a convincing preference for the CD-ROM version over the print version because respondents found it faster and easier to search on the electronic version.

Art galleries and museums were quick to take advantage of the possibilities of the compact-disc interactive (CD-I) technology to make their collections available to artists and art scholars. This multimedia format combines text, audio, visual, graphics, photographs and animation into a single programme (Kerr 1993:202) and through the interactive capabilities, users can magnify parts of paintings, compare different works and generally explore the gallery as they wish. The Louvre, National Gallery of London and several others now have CD-ROMs available.

\section{Internet}

The Internet provides a new way for scholars to search for information and images electronically. Most of the major art galleries have web sites. There are several indexes to art sources available and the visual arts departments of several universities worldwide have interesting web sites. Several art periodicals are available in full-text through the Internet and there are many other ways of accessing information through this network.

The e-mail facilities on the Internet, bulletin boards, computer conferencing and listservs available provide a valuable global invisible college with other scholars (Greenhalgh 1996:99). An example of a listserv is ArtServe Australian National University (http://rubens.anu.edu.au).

It would be valuable to discover to what extent visual arts scholars and researchers have adapted their informationseeking habits in line with these technological developments.

\section{Statement of the problem and hypotheses}

The main problem which is under consideration in this empirical investigation is the information-seeking behaviour of the artist as a scholar. This includes why, how and where he looks for the information he needs.

The subjects included in the sample are the full-time lecturers at the Vaal Triangle Technikon who specialise in various fields of the fine and applied arts. In the first group are art historians, lecturers in practical fine arts and ceramicists and in the latter group are graphic designers, photographers and multimedia system specialists.

The subjects come from a wide range of academic backgrounds, and the information-seeking behaviour of the various types of artists and those with different levels of qualifications will be investigated to determine the similarities and differences relating to the information-seeking patterns of the groups in question. Other variables which will be considered are the gender and the age of the respondents which might have a bearing on the ways in which the artists look for information.

The main hypothesis is that the information needs and information-seeking behaviour of artists differ according to the branch of visual arts in which they specialise and is affected by the gender, age and education level of the respondents.

Although artists also require information for their artistic inspiration and creative pursuits, as was investigated by Cobbledick (1996), this aspect of the information-seeking behaviour in visual artists will be excluded from this survey.

It is also possible that the arts lecturers in the applied arts might make greater use of electronic media to find information than those in the fine arts because scholars in the applied arts work with digital equipment in the course of their artistic activities, unlike many of the fine arts scholars.

Another aspect of information-seeking behaviour investigated in this survey is the use made of abstracting and indexing databases and tools by this sample.

Because art information includes both visual and textual information, including representations of works of art and text about these works (Layne 1994:24), the way in which artists use visual information should also be investigated. This is particularly important because it is a need experienced primarily by scholars in the arts. 


\section{Sampling method}

The population from which the sample of artists and art historians was drawn is lecturers at Technikons in South Africa, and more specifically lecturers at the Vaal Triangle Technikon in Vanderbijlpark. The population includes fulltime and part-time lecturers, heads of departments, deans of faculties and also technical assistants. The sample selected is all full-time staff in the art department at the Vaal Triangle Technikon.

There is a clear distinction between the lecturers in the fine arts and those in the applied arts as mentioned above. Fine arts scholars are more concerned with the creation, evaluation, study and criticism of various aspects of works of art and the artists who created them and also with the creation of original works of art by themselves and their students. Those in the applied arts are involved with various aspects of graphic design and illustration used for commercial purposes and image manipulation by digital means (in the field of graphic design) and with the history and techniques of all aspects of photography, multimedia and digital manipulation of photographic images (in the field of photography).

Full-time lecturers spend approximately eight hours on the campus each working day. Much of their time is taken up with lecturing and tutoring students. Most have access to the Internet through computers in their offices. The technikon library is very close to the Departments of Fine Arts, Graphic Design and Photography and there has always been a good relationship between the department and the library staff. The subject librarian for the department is the main contact point between the library and arts lecturers and is always available to help with collection development, information needs and any other problems the lecturers in question might encounter. The requests of lecturers are given precedence in deciding which sources should be purchased for the library. From this it can be inferred that the collection has developed according to the needs of the lecturers themselves.

\section{Data collection}

The instrument selected for the survey was a selfadministered questionnaire which was pre-tested on students in the department concerned. The questionnaire was constructed as follows:

- Questions 1-4: Demographic information

- Question 5: Information needs

- Questions 6-18: Usefulness of various information sources

- Questions 19-24: Preferred methods of looking for information

The questionnaire includes open- and closed-ended questions and respondents had to answer every question.

Questionnaires were sent to 18 subjects with cover letters. To keep track of the return of the questionnaires and because the data was not of a very confidential nature, no attempt was made either to identify the respondents or to conceal their identity, and many questionnaires were returned with the accompanying cover letters, making it easy to identify those who had not responded.

After two weeks, questionnaires were again sent to those who had not returned the questionnaires. The number of questionnaires returned was 15 (a response rate of $83 \%$ ). This response will be considered adequate to evaluate the information-seeking behaviour of the sample.

\section{Data analysis}

The sample is composed as follows:

\section{Gender}

Female: 9 Male: 6

Age group

$\begin{array}{ccccc} & \text { Below 30 } & 30-39 & 40-49 & 50+ \\ \text { No. of respondents } & 2 & 7 & 4 & 2\end{array}$

\section{Qualifications}

- National Diploma: 3

- Nat. Higher Dip.: 3

- BA (Fine Arts) - in some cases coupled with other qualification: 4

- BA (Fine Arts) Hons.: 1

- MA (Fine Arts): 3

- Laureatus: 1

\section{Special field of interest in the arts}

- Art history and theory: 3

- Graphic design: 3

- Fine arts (Practical): 7

- Photography (Multimedia): 1

- Ceramics: 1

\section{Information needs of scholars in the arts}

Respondents had to indicate in order of importance the reasons why they look for information. Overall, the most important reasons for looking for information were 'studying for a higher qualification' (five respondents) and 'personal interest and curiosity' (five respondents).

As the second most important reason, 'development of new curriculum', which includes lecture preparation and all aspects of teaching drew six responses and 'studying for a higher qualification' was chosen five times.

As the third most important reason for looking for information, four respondents need information for 'writing an article for a periodical' and four out of 'personal interest and curiosity'.

The most vital need for information (first, second and third choices added together) is for further studies for higher qualifications (13). The second most important need was personal interest and curiosity (12). These are followed by teaching and curricular requirements (9) and article writing (8). Other reasons given as the most important reason for seeking 
information were for practical art work (1) and for keeping abreast with new developments in industry (1).

When correlated according to the qualifications of respondents, certain features emerge. Generally speaking, the diplomates (those with National Diploma and National Higher Diploma) in the sample need information mainly for further studies and out of personal interest, followed by the need for information for teaching and curriculum development. This group has little need for information for authorship of periodical articles. Graduates consider personal interest and curiosity their most important information need, followed by further studies and then the writing of articles. Post graduates need information mainly for further studies and the writing of periodical articles. This is followed by personal interest. University-educated artists show a much greater interest in seeking information for the writing of articles than do Technikon diplomates.

\section{Choice of information sources used}

Figure 1 shows the preferred information sources used by artists in general. Whereas Budd (1989:12) found that $66.4 \%$ of fine arts researchers preferred using books as information sources, as opposed to $25.3 \%$ of respondents preferring periodical articles, this survey shows that periodical articles are considered essential by $87 \%$ of the respondents (13 subjects), whilst $73 \%$ (11) of the respondents found library books essential information sources. Overall, periodical articles are considered the most essential source in this survey. Personal contact with colleagues and other scholars shared second place with the use of library books.

Bearing out previous findings that artists' private collections are valuable sources of information (Lönnqvist 1990: 201), ten (67\%) of the respondents found their own collection of books essential sources. The same number found visits to galleries essential.

An interesting finding is that exhibition catalogues, which are the printed records of the exhibitions in these

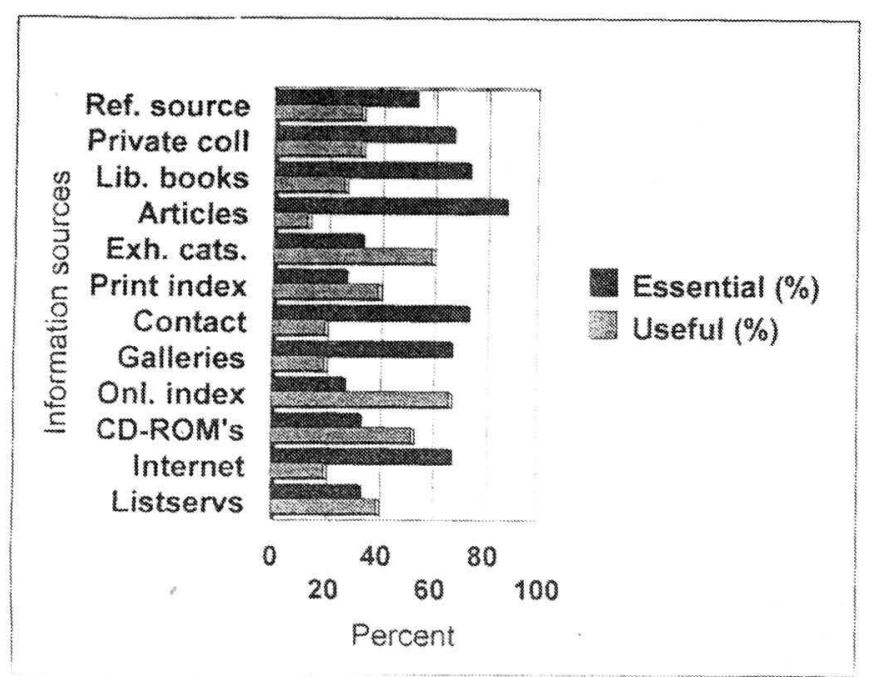

Figure 1 Preferences in use of various types of information source galleries, were not found as useful as expected. Only five respondents $(33 \%)$ found these essential sources, whilst nine (60\%) found them useful. Layne (1994:33), in her survey, found that artists make extensive use of these catalogues. Because of the scarcity of documentation regarding South African artists, it is possible that an investigation of information-seeking behaviour regarding South African art would show more of an inclination towards exhibition catalogues.

The other print media under investigation, that is reference books like encyclopaedias, were found to be essential to eight $(53 \%)$ of the respondents, which again deviates somewhat from previous findings (Rees 1989:28). The library in question has owned the new art encyclopaedia, Dictionary of art edited by Jane Turner, for a few months only. Perhaps lecturers will find this source more valuable as they become more familiar with its use.

The print indexing and abstracting journals (Art index is available in the library) do not appear to be very valuable to the respondents in question. Only four (27\%) found them essential, and six (40\%) found them useful.

Of the electronic media available to artists today, the most popular in this sample is the Internet with ten $(67 \%)$ of the respondents finding this source essential.

Although online indexing and abstracting databases are found useful by the majority (10 or 67\%) of the respondents, only four $(27 \%)$ consider these databases essential. This could possibly be attributed to the fact that these databases are not available to artists directly through the library network at present. The librarians have to be consulted for online searches. Those respondents who do find these information sources essential have made comments emphasizing the great store they place on these bibliographic sources. It seems that those researchers who know how these indexes are used find them extremely useful. It must be mentioned, however, that the online indexing databases are decidedly more popular than their print equivalents.

Because the Art Department at the Technikon, and the library concerned, are only now starting to acquire artrelated CD-ROMs, it is not surprising that the interest shown in this medium as an information source is lacking. Only five $(33 \%)$ of the respondents consider these essential, and eight (53\%) find them useful sources. More affluent and technologically advanced institutions might show different results because this growing industry includes very valuable, but very expensive, visual and multimedia information for artists. This researcher believes that the lack of interest in this medium is directly related to a lack of knowledge of the capabilities of these CD-ROMs.

The use of listservs, bulletin boards and e-mail evoked little enthusiasm from respondents. Whilst only five (33\%) found these information sources essential, six (40\%) found them useful. This finding was surprising, especially in view of the fact that the Internet is obviously held in high esteem by the respondents. There are considerable problems 
relating to the campus-wide network, which might have an influence on the popularity of these means of scholarly communication. The artists concerned might consider these means of looking for information too difficult at the moment, and prefer the more familiar means of finding information.

As found by other researchers print media like books and periodicals remain popular means of finding information. Personal contact with other artists is also very common, and the use of the Internet is popular.

\section{Comparison of information source preferences by various groups}

In order to determine whether the variables of gender, age, qualifications and field of study in the visual arts influences information-seeking behaviour of artists, these factors will now be brought to bear on the data.

\section{Gender}

It is clear when one studies Figure 2 that information source preferences of male and female respondents are very divergent. This figure gives only the number of respondents who consider the various sources 'essential'.

The first marked difference is in the use of print media. Female respondents rely much more heavily on their own collections and on the library (eight out of nine respondents [89\%] in both cases) than do their male counterparts. Of the male respondents, only two out of six (33\%) find their private collection of books essential information sources, and only three $(50 \%)$ consider the library's collection of books essential.

The other variable which shows a distinct difference is the use of electronic communication channels like listservs, bulletin boards and e-mail for contact with other scholars. Only one of the female respondents found this an essential source $(11 \%)$, whilst four $(67 \%)$ of the male respondents favour this as an essential information source. It must be added that five $(56 \%)$ of the female respondents indicated that these channels were useful information sources. There

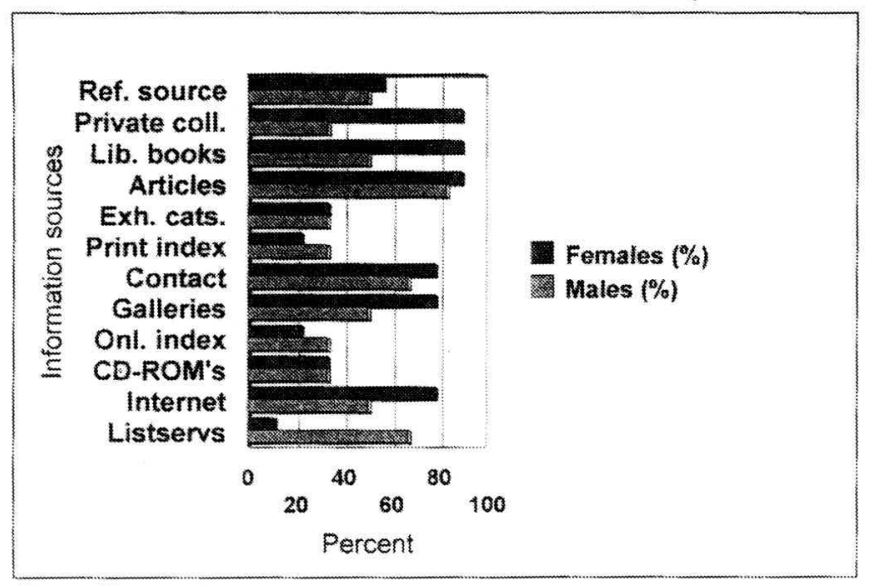

Figure 2 Gender differences in information source preferences were slight differences in the other variables, but by and large the trends were similar.

\section{Age group}

The data indicates that there are discrepancies in information source preferences between the various age groups - most particularly between the under 40 group and the over 40 group.

As seen in Figure 3, the over 40 group shows a penchant towards print media, especially in their use of reference sources (40-49 age group only - 75\%), library books (100\%), and exhibition catalogues (again 40-49 group only $-75 \%$ ). This group also finds periodical articles essential sources (five respondents out of six $-83 \%$ ), but the latter is also reflected in statistics relating to the under 40 group (eight respondents - 89\%).

As far as visiting galleries is concerned, all groups but the $40-49$ group were $100 \%$ in favour of using these as sources. In the 30-39 age group, only two out of seven (29\%) find galleries essential reference sources.

The 40-49 age group was the only group to favour printed indexing and abstracting tools (two out of four $50 \%)$.

The younger group seems to have embraced electronic media more readily than the older group, which would be explained in the light of the 40+ age group having to come to grips with electronic media in their adult lives, whereas the younger group grew up in the computer age.

Online indexing and abstracting databases are essential to three out of nine respondents in the under 40 group (33\%), and useful to six $(67 \%)$. In the over 40 group, these sources are essential to one out of six (17\%), and useful to four out of six $(67 \%)$.

The Internet use of the two groups shows little difference - making this source valuable to all age groups, but there is a clear discrepancy in use of listservs et cetra between the age groups. The 30-39 group especially favours this

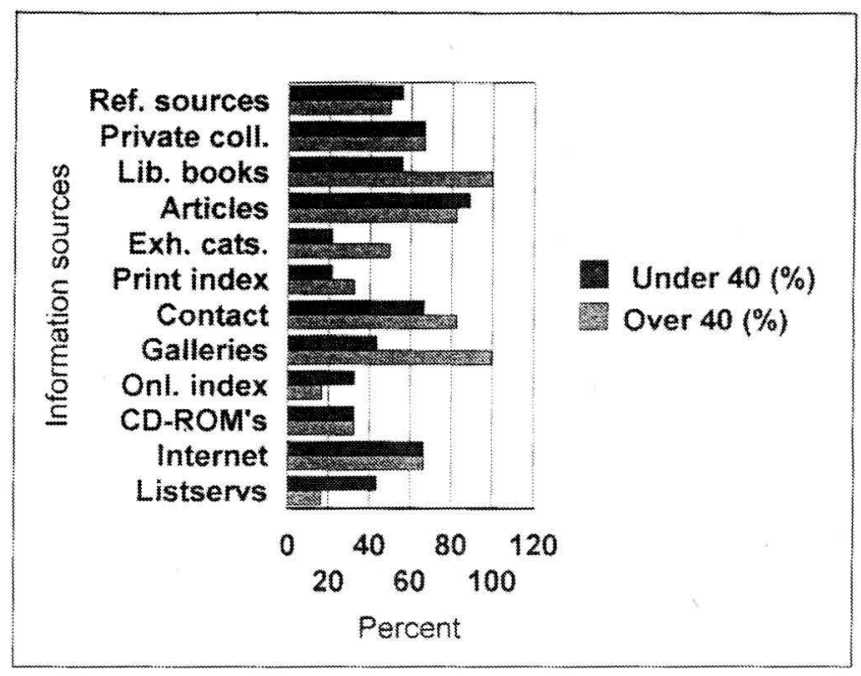

Figure 3 Age differences in the choice of information sources 
medium (four out of seven $-57 \%$ ) as opposed to one out of six $(17 \%)$ of the over 40 group.

\section{Qualifications}

There is a close correlation between respondents with bachelors degrees (in several cases these respondents have additional qualifications as well) and those with a National Diploma or National Higher Diploma. The only small difference is that the former group shows slightly more interest in the use of print indexing and abstracting journals, whilst the latter group places slightly more store on the Internet and listservs et cetera as information sources.

There is however a notable difference between these two groups and those with postgraduate qualifications (see Figure 4).

The graduates and diplomates consider print media more valuable than do the postgraduates. Altogether $80 \%$ of the former group of ten respondents consider books in their private collections to be essential as opposed to two out of five $(40 \%)$ of the postgraduates. The same number of the graduate and diplomate group (80\%) find library books essential, compared to three out of five postgraduates $(60 \%)$. An exception occurs in the areas of exhibition catalogues and print indexes where three $(60 \%)$ of postgraduate respondents find these sources essential, as opposed to two out of ten $(20 \%)$ and one (10\%) of the other group for each of these sources respectively.

Personal contact is also more important for postgraduates; $100 \%$ of this group consider this essential, as against $60 \%$ of the other group. Visits to art galleries are favoured by $100 \%$ of the postgraduate group, as opposed to $50 \%$ of the other group, making this information source more important to the postgraduates than to the other respondents.

A clear trend emerges when it comes to electronic media, which is favoured throughout by the postgraduate group (see Figure 4). Three respondents in the postgraduate group $(60 \%)$ of this sample find online indexing databases

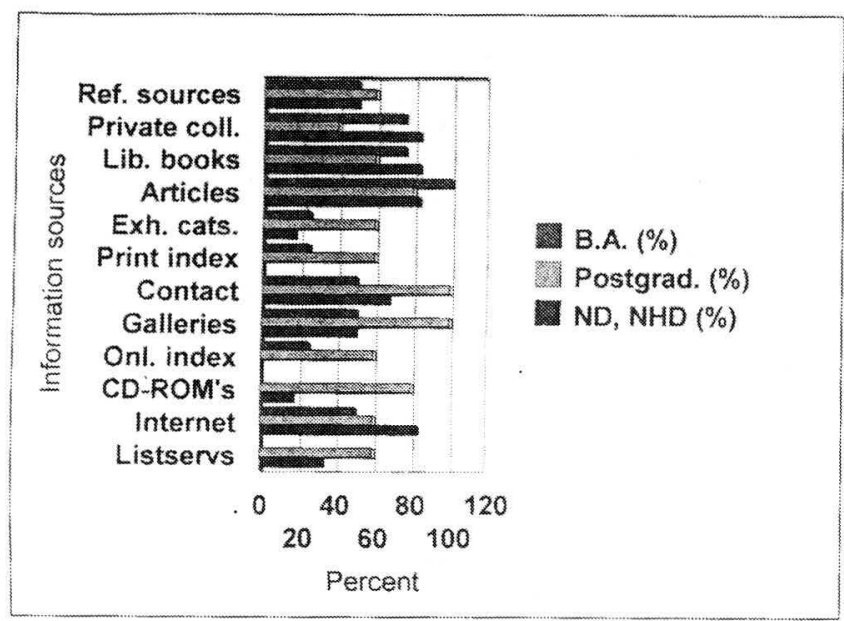

Figure 4 How qualifications effect choice of information sources essential as against one (10\%) of the other group. Four $(80 \%)$ of the postgraduates favour CD-ROMs against one $(10 \%)$ of the other group, and three $(60 \%)$ of the former group consider listservs, bulletin boards and e-mail essential, as against two (20\%) of the other respondents.

\section{Fine arts versus applied arts}

Data comparing these two areas of art can be seen in Figure 5.

Predictably, visiting art galleries and referring to exhibition catalogues are more valuable to fine arts scholars than to those in the applied arts. This can largely be attributed to the fact that it is mainly artists in the fine arts who exhibit their work in this way. Nine out of 11 $(82 \%)$ of fine arts scholars consider visits to galleries essential, whilst only one out of four $(25 \%)$ of scholars of the applied arts found these valuable. The private collections of the lecturers in the applied arts are valued as essential by $100 \%$ of these respondents, as opposed to six out of $11(55 \%)$ of fine arts lecturers.

To date, there are more CD-ROMs relating to the fine arts than to the applied arts, and predictably fine arts scholars show a greater liking for this medium (four respondents $36 \%)$ as against one $(25 \%)$ of the scholars of the applied arts.

The Internet and listservs et cetera, however, are clearly considered valuable in the area of the applied arts with $100 \%$ of this group considering the Internet to be essential as opposed to six (55\%) of the other group. Listservs, bulletin boards and e-mail are also essential to $50 \%$ of the applied arts scholars as against three $(27 \%)$ of the other group.

The needs of the scholars in graphic design and photography do not seem to be adequately met by the conventional print media available. Another source of information mentioned is suppliers of equipment and

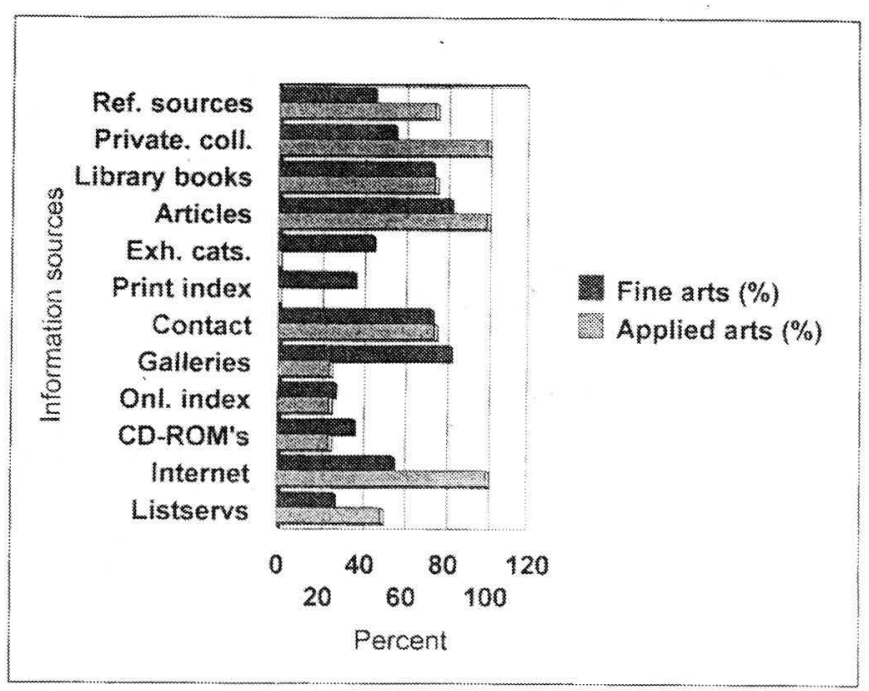

Figure 5 Differences in choice of information sources between fine and applied arts 
materials. Personal or electronic contact with people in the advertising and design industries is found invaluable to these scholars.

Several of the fine arts scholars made particular mention of the importance of interviewing and personal contact with other artists as an essential information source. Visits to the actual sites and countries being studied are also considered essential by one of the respondents.

\section{Ways of looking for information}

The artists and visual arts scholars in the sample were also asked to indicate how useful they find certain methods of looking for information. Cobbledick (1996) interviewed four artists to discover their information-seeking habits. The sculptor (1996:349) prefers to browse or ask a subject librarian, but avoids catalogues of any kind. The painter and the fibre artist she interviewed browse or use the OPACs but seldom consult subject librarians. Some of these searching habits were confirmed in this survey.

Overall, the following pattern emerged as shown in Figure 6.

A self-conducted catalogue and Online public access catalogue (OPAC) search seems to be the most popular way in which artists look for the information they require. This supports previous research findings that artists prefer to find their own information (Budd 1989:9). Eight out of 15 $(53 \%)$ considered this a vital means of getting information, and another six (40\%) found it useful. The second most popular means of finding information amongst artists in this sample (seven respondents $-47 \%$ ) is to ask a librarian. This also comes as no surprise because of the good relationship between faculty members and subject librarians. This method has also been found to be popular in previous investigations (Cobbledick 1996:349).

Another popular means of looking for information amongst the artists is the Internet. Six (40\%) of the

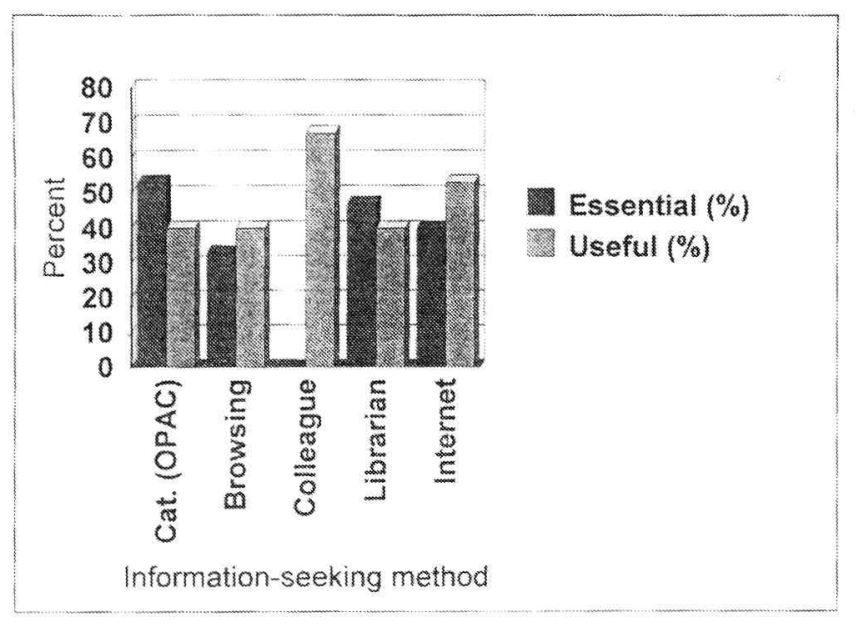

Figure 6 Preferred ways of looking for information amongst artists respondents consider this method essential for finding information.

Browsing through the shelves in the library was essential to only five (33\%) of the artists and asking friends or colleagues for help in finding information lacked any support as a search method.

\section{Gender}

Again, when one looks at the information-seeking methods preferred by the different genders, some new trends come to light. (See Figure 7).

The female artists find conducting own searches on catalogues and OPACs the best way of finding information (six out of nine $-67 \%$ ). This method was found essential by only two out of six (33\%) of the male respondents.

Another difference is that whilst five $(56 \%)$ of the female artists cast their vote for browsing amongst the shelves as essential, none of the male respondents considered this method vital; four (67\%) found it useful, however, indicating that male artists do indeed use this method, albeit as a second option.

In the matter of asking a librarian, male respondents (three respondents $-50 \%$ ) found this method essential, as opposed to four $(44 \%)$ of the female respondents. This method was the favoured method amongst the male artists.

\section{Age group}

It seemed logical to divide age groups again into the below 40 and the above 40 group as only minor deviations occur when one divides the groups further.

The most obvious differences between these groups occur in preferences for asking a librarian and for conducting searches on the Internet.

The above 40 group found the option of asking a librarian essential as a search method (four out of six $-67 \%$ ). Of the

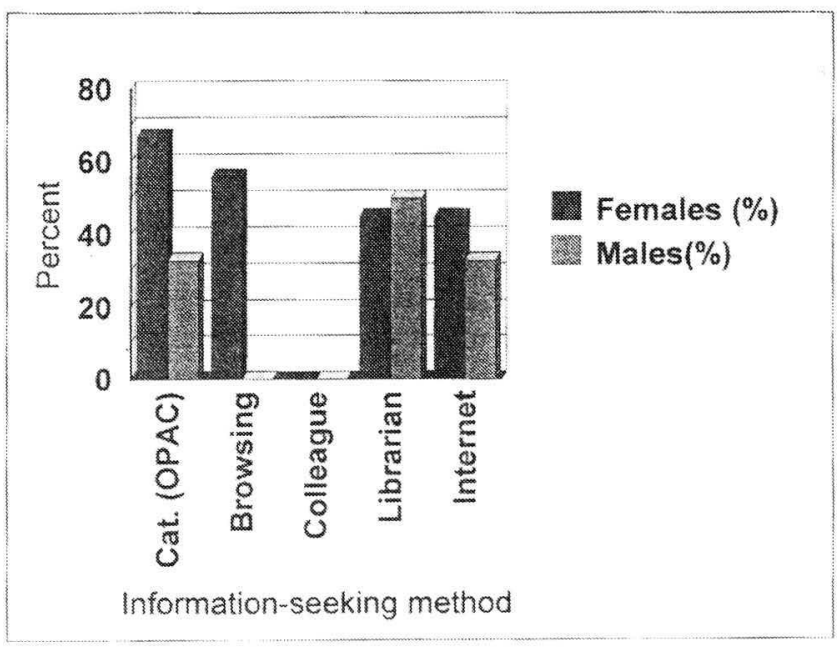

Figure 7 Gender differences in the way artists look for information 
under 40 groups, only three out of nine $(33 \%)$ preferred this method.

Conducting own searches on the Internet was clearly the preferred method of the under 40 group with five $(56 \%)$ finding this method essential. In contrast, only one (17\%) of the older group felt the same. Of the over 40 group it must be said that five ( $83 \%$ ) found this method useful. This bears out the hypothesis that younger artists who are more familiar with computer technology will feel more at home with this information resource. (See Figure 8).

\section{Qualifications}

Qualifications do not appear to alter radically the ways in which artists search for information (Figure 9).

One area which shows some discrepancy is browsing through shelves to find information. Although $50 \%$ of graduates and diplomates find this an essential information-seeking method, no postgraduate arts scholars share this view.

Another information-seeking method which differs according to the qualifications of the artist, is asking a librarian for assistance. Whilst four out of five (80\%) of the postgraduate group find this method essential, only five out of ten $(50 \%)$ of the graduate and diplomate group share this view. $\backslash$

\section{Fine arts versus applied arts}

There are definite indications (Figure 10) that scholars in the fine arts practise different information-seeking habits than scholars in the applied arts.

Fine arts scholars, for example, show a greater tendency to use catalogues and OPACs (six out of 11 respondents $55 \%)$ than scholars in the applied arts (50\% of respondents - two out of four). This could be attributed to the fact that titles and subject headings for the fine arts are more varied and descriptive than those in the applied arts. Whereas many sources could bear the subject headings 'graphic arts'

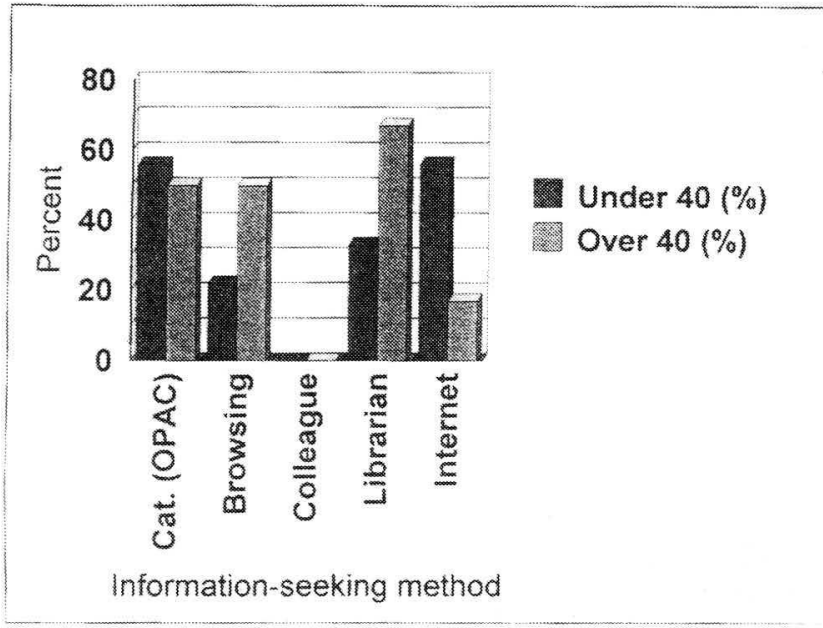

Figure 8 Age differences in the way artists look for information

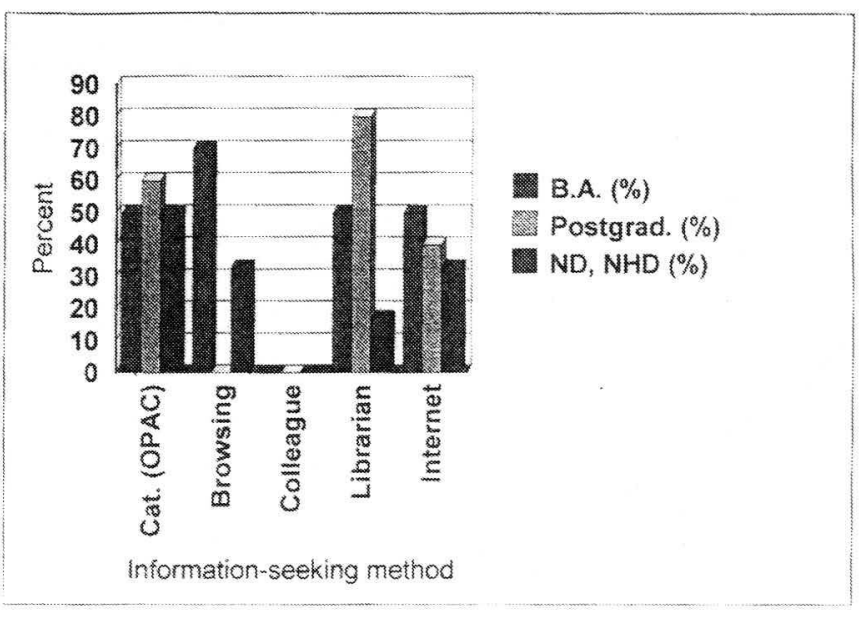

Figure 9 Qualifications as a variable in preferred information-

or 'photography - technique' in the field of the applied arts even though they might deal with very different subject matter, in the fine arts sources can be described according to the name of the artist, art movement, nationality and period of the artist and even sometimes the theme of the works of art, et cetera. These are more easily retrievable in a subject or title field in catalogues. It might be essential for applied arts scholars to examine the actual sources and scrutinise each source's index to find the information required. This is borne out to some degree by the fact that whereas $50 \%$ of applied arts scholars find browsing an essential method, only three $(27 \%)$ of the fine arts scholars share this view.

Another significant difference is that the fine arts lecturers use the help of librarians more than do those in the applied arts; seven (64\%) of the fine arts lecturers find the help of librarians essential. None of the applied arts group

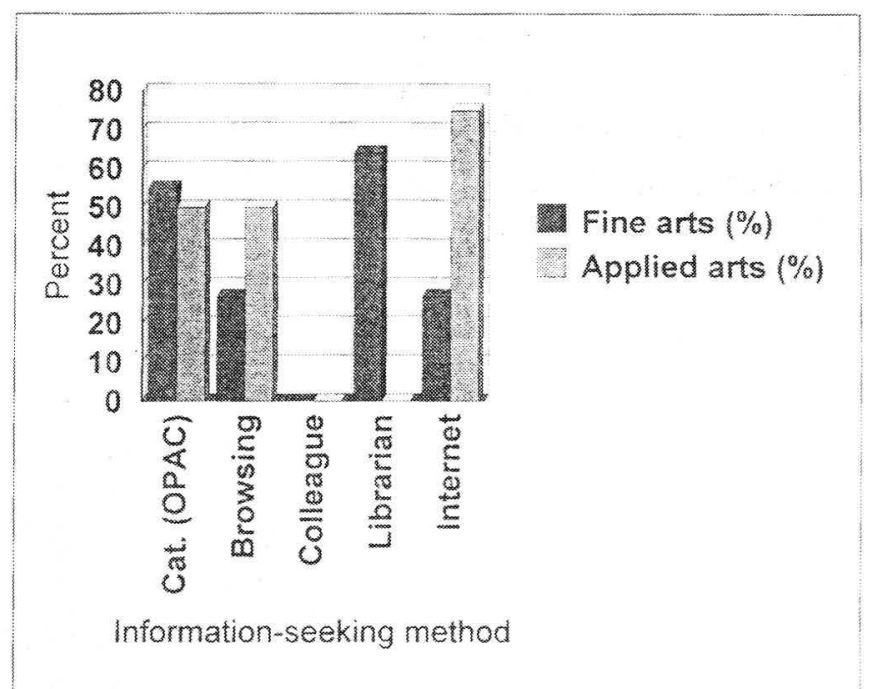

Figure 10 Ways of looking for information - fine arts versus applied arts 
share this view - although three out of four (75\%) find librarians' help useful.

It was also found that scholars in the applied arts show a greater tendency to use the Internet as an essential search method than those in the fine arts. It was found that $75 \%$ of the former group of scholars find the Internet essential whilst only three $(27 \%)$ of the fine arts scholars shared this view. This also confirms the hypothesis that applied arts researchers who work more with technology are more likely to use electronic means of finding information.

\section{Conclusions and recommendations}

There are clearly differences in the information-seeking behaviour and information needs of the various groups defined in this empirical investigation. The age, gender, field of interest and level of qualification of the artist and arts scholar is a deciding factor in the ways in which they. find the information they require.

There is an indication that the trend is moving slightly away from print media towards electronic means of information retrieval and that this trend is likely to continue as a new generation of art scholars become major information seekers.

In the light of these findings, it seems unlikely, however, that print media and library use will easily fall into disuse amongst artists. These means of finding information are still widely used and the activity of browsing through sources to come upon that unknown source or piece of information has a certain charm which is lacking in electronic means of looking for information.

The trend towards increased use of the Internet, online indexing databases and CD-ROMs especially has implications for information-providing facilities like libraries and information services. Multimedia systems should be made available to users to provide for the use of art-related CDROMs and users should be given access to online databases. This latter point is important in the light of the finding that artists like to look for their information themselves before seeking help from librarians.

Another aspect of library services which might require attention, is in the provision of an adequate supply of arts periodicals and also of exhibition catalogues. These sources were found to be valuable to arts scholars.

Because the Internet is such a valuable source of information, the library should provide access to this network for scholars, or alternatively organise the information available to facilitate Internet use for inexperienced users. Information specialists are in a good position to create artrelated intranets with links to valuable Uniform Resource Locators (URLs), or perhaps they could create "clearinghouses' where important material for artists is brought together for users at one web site.
In order to remain relevant to the information-seeking needs of artists, information providers should take cognizance of the changing information-seeking patterns of artists and strive to adapt services and facilities in line with these new needs, whilst still providing a print collection of relevant media which is of a high quality to meet the more traditional (and still important) needs of artists.

Pratchett (1995:287) illustrates the point of misunderstanding people's needs very well. Rincewind comes across one of many peasants who seem to stand around all day ankle deep in a wet field holding a grazing water buffalo on the end of a length of string. As this man is obviously unaware of the fact that a bloody battle is about to erupt nearby to improve the living conditions of the oppressed and liberate the poor from enslavement, he asks the peasant what he really wants out of life and from the struggle going on on his behalf, and the answer to this is: 'A longer piece of string would be nice'. Continued research into this field of study should lead one closer to understanding the real needs and providing that longer piece of string art scholars require of an information service.

\section{References}

Allen, B. 1990. The effect of academic background on statements of information need. Library quarterly, 60(2):120-138.

Brittain, J.M. 1982. Pitfalls of user research and some neglected areas. Social science information studies, 2:139-148.

Brown, R.C.W. 1990. Changing patterns of scholarly communication and the need to expand the library's role and services. Library acquisitions, 14:371-377.

Budd, J.M. 1989. Research in the two culture: the nature of scholarship in science and the humanities. Collection management, 1 (3/ 4): $1-21$.

Campbell, D. \& Campbell, M. 1995. The student's guide to doing research on the Internet. Reading: Addison-Wesley.

Case, D.O. 1986. Collection and organization of written information by social scientists and humanists: a review and exploratory study. Journal of information science, 12:97-104.

Cobbledick, S. 1996. The information-seeking behavior of artists: exploratory interview. The library quarterly, 66(4):343-372.

Cronin, B. 1982. Progress in documentation. Journal of documentation, 38(3):212-236.

Dunn, K. 1986. Psychological needs and source linkages in undergraduate information-seeking behavior. College \& research libraries, September:475-481.

Glicksman, M. 1990. Changing patterns of scholarly communication: implications for libraries. Library acquisitions: practice \& theory, 14:341-346.

Horton, W.J. 1993. Research methods and data gathering techniques in the arts and social sciences. Education for information, 11:6567.

Greenhalgh, M. 1996. Setting up and exploiting humanities research resources on the World Wide Web. Australian academic \& research libraries, 27(6):95-106.

Jacso, P. \& Tiszai, J. 1996. Multimedia databases of fine arts CDROM and online. Database, 19(6):13-89.

Kerr, L. 1993. Compact disc interactive: improving access to information for disabled people. Audiovisual librarian, 19(3):202204. 
Layne, S.S. 1994. Artists, art historians, and visual art information. The reference librarian, 47:23-35.

Leedy, P.D. 1993. Practical research: planning and design. New York: MacMillan.

Lönnqvist, H. 1990. Scholars seek information: informationseeking behaviour and information needs of humanities scholars. International journal of information \& library research, 2(3):195-203.

Muratori, F. 1989. How good an online searcher are you? Twenty questions about arts and humanities databases. Online, 13(1):40-42.

Palmer, R.C. 1992. Automation in the arts: coordinating the experts. Art documentation, 1 1(Fall):121-123.

Pratchett, T. 1995. Interesting times. London: Corgi.

Rees, J. 1994. Information access versus document supply: the International Visual Arts Information Network project. Interlending \& document supply, 22(1):20-24.

Robertson, J. 1989. The exhibition catalog as source of artists' primary documents. Art libraries journal, 14(2):32-36.

Ross, A. 1987. Visual arts research: a handbook. Art libraries journal, 12(2):27-28.
Sacca, E.J. \& Singer, L.R. 1984. Visual arts reference and research guide for artists, educators, curators, historians and therapists. Art libraries journal, 9(Summer):80-82.

Shipe, T. 1991. The monographic cataloger and the artist's book: the ideal reader. Art documentation, 10(Spring):23-25.

Skelton, B. 1973. Scientists and social scientists as information users: a comparison of results of science user studies with the investigation into information requirements of the social sciences. Journal of librarianship, 5(2):138-155.

Stone, S. 1982. Progress in documentation. Journal of documentation, 38(4):292-313.

Sykes-Austin, B. 1991. The Art Index on CD-ROM at the Avery Architectural and Fine Arts Library, Columbia University: a research study. Art documentation, 10(Spring):13-17.

Walter, N. 1991. Computerization in research in the visual arts. Art documentation, 10(Spring):3-11.

Wieben, S. 1995. 'That big painting by Michelangelo. You know the one.' The unabashed librarian, 96:21.

Wood, D.N. Discovering the user and his information needs. Aslib proceedings, 29(2):262-270. 